\title{
Kemampuan Literasi Matematika Ditinjau dari Gaya Belajar
}

\author{
Sefna Rismen ${ }^{1}$, Widya Putri², Lucky Heriyanti Jufri ${ }^{3}$ \\ Program Studi Pendidikan Matematika, STKIP PGRI Sumatera Barat \\ Jl. Gn. Pangilun, Padang Utara, Sumatra Barat \\ widyaputri717@gmail.com
}

\begin{abstract}
Mathematical literacy skills are very important for students because they can help students understand the role or use of mathematics in everyday life and make rational and logical judgments and decisions. One of the factors supporting the ability of mathematical literacy is the student's learning style. This study aims to analyze students' mathematical literacy skills in terms of learning styles. This type of research is a descriptive method with a qualitative approach. The research population was seventh grade students of SMP N 14 Padang. The research sample for class VII 6 was taken by purposive sampling. The instruments used are in the form of a learning style questionnaire, a mathematical literacy ability test and interview guidelines. The data analysis technique uses the Miles \& Huberman model, namely data reduction, presentation, and conclusion. The results of this study indicate that mathematical literacy skills based on students' learning styles can be concluded that visual and auditory learning styles are mostly on reproductive competence, while kinesthetic students' learning styles are on connection competence. Based on the results of this study, teachers are expected to be able to choose the right method according to student learning styles for improve students' mathematical literacy skills.
\end{abstract}

Keywords: Mathematical Literacy Ability, Learning Style, Reproduction, and connection

\begin{abstract}
Abstrak
Kemampuan literasi matematika sangat penting dimiliki oleh siswa karena dapat membantu siswa untuk memahami peran atau kegunaan matematika dalam kehidupan sehari-hari dan membuat penilaian serta keputusan secara rasional dan logis. Salah satu faktor pendukung kemampuan literasi matematika adalah gaya belajar siswa. Penelitian ini bertujuan untuk menganalisis kemampuan literasi matematika siswa ditinjau dari gaya belajar. Jenis penelitian ini adalah metode deskriptif dengan pendekatan kualitatif. Populasi penelitian adalah siswa kelas VII SMP N 14 Padang. Sampel penelitian kelas VII 6 yang diambil secara purposive sampling. Instrumen yang digunakan yaitu berupa angket gaya belajar, tes kemampuan literasi matematika serta pedoman wawancara. Teknik analisis data menggunakan model Miles \& Huberman yaitu reduksi data, penyajian dan pengambilan kesimpulan. Hasil penelitian ini menunjukkan bahwa kemampuan literasi matematika berdasarkan gaya belajar siswa dapat di disimpulkan bahwa gaya belajar visual dan auditorial lebih banyak berada pada kompetensi reproduksi sedangkan gaya belajar siswa kinestetik berada pada kompetensi koneksi. Berdasarkan hasil penelitian ini diharapkan guru untuk dapat memilih metode yang tepat sesuai dengan gaya belajar siswa agar dapat meningkatkan kemampuan literasi matematis siswa.
\end{abstract}

Kata kunci: Literasi Matematika, Gaya Belajar, Reproduksi dan Koneksi

Copyright (c) 2022 Sefna Rismen, Widya Putri, Lucky Heriyanti Jufri

$\triangle$ Corresponding author: Widya Putri

Email Address: widyaputri717@gmail.com (Jl. Gn. Pangilun, Padang Utara, Sumatra Barat)

Received 27 October 2021, Accepted 18 January 2022, Published 18 Januari 2022

\section{PENDAHULUAN}

Pendidikan abad ke-21 menuntut semua orang mengembangkan seluruh kompetensi yang dimilikinya, salah satunya adalah kemampuan literasi. Kemampuan literasi matematika sangat penting untuk dimiliki oleh siswa karena, dapat membantu siswa menggunakan matematika dalam kehidupan nyata, menggunakan metode yang efisien untuk pemecahan masalah, melakukan penilaian apakah hasil yang diperoleh masuk akal serta menganalisis situasi dan menarik kesimpulan (Genc et al., 2019). Literasi matematika juga menuntut siswa untuk mengkomunikasikan dan menjelaskan fenomena yang dihadapinya dengan konsep matematika. Hal ini sejalan dengan definisi literasi 
matematika yang merupakan kapasitas individual untuk memformulasikan, menggunakan, dan menafsirkan matematika dalam berbagai konteks. Kemampuan meliputi penalaran matematika dan menggunakan konsep, prosedur, fakta, dan alat matematika untuk mendeskripsikan, menjelaskan, dan memprediksi fenomena (OECD, n.d.).

Kemampuan literasi matematika siswa menurut PISA terdapat 3 kelompok yaitu kelompok Reproduksi, kelompok Koneksi dan kelompok Refleksi (Thomson et al., 2013). Kelompok Reproduksi, siswa menafsirkan representasi sederhana dan permasalahan yang familiar, melakukan perhitungan sederhana dan prosedur untuk menyelesaikan masalah rutin. Kelompok Koneksi, siswa mengintegrasikan dan menghubungkan seluruh konten, situasi dan representasi penyelesaian masalah non rutin dengan menggunakan beberapa metode yang jelas dalam penalaran matematika yang sederhana. Kelompok Refleksi, siswa memecahkan masalah yang kompleks, menemukan ide tentang matematika, menggunakan banyak metode kompleks untuk membuat generalisasi dalam memecahkan masalah.

Hasil survei yang dilakukan oleh lembaga-lembaga internasional seperti Trend in International Mathematics and Science Study (TIMSS) dan Program for International Student Assessment (PISA) yang menempatkan Indonesia pada posisi yang belum cukup memuaskan di antara negara-negara yang di survei. Hasil survei TIMSS tahun 2015 mencatat bahwa Indonesia menempati posisi ke 45 dari 50 Negara di bidang Matematika.1 Demikian pula PISA tahun 2015, yang mencatat bahwa Indonesia hanya menempati posisi ke 62 dari 70 Negara pada bidang literasi matematik (OECD, n.d.). Hasil penelitian yang dilakukan oleh (Wijaya et al., 2014), menyatakan siswa di Indonesia mengalami kesulitan dalam memecahkan soal matematika PISA yang berbasis konteks dan mengubahnya menjadi masalah matematika. Penelitian yang dilakukan oleh (Khoirudin, A., Setyawati, R. D., \& Nursyahida, 2017) menemukan bahwa siswa dengan kemampuan matematis rendah hanya mampu menyelesaikan soal level 1.

Berdasarkan hasil obeservasi dan wawancara yang dilakukan pada siswa SMP N 14 Padang juga ditemui permasalahan rendahnya kemampuan literasi matematis siswa, hal ini ditandai dengan kesulitan siswa dalam memecahkan permasalahan yang diberikan, siswa kesulitan tersebut tanpak pada saat siswa tidak menuliskan apa yang ditanyakan pada soal, siswa juga tidak dapat menemukan pertanyaan penting pada soal, sehingga dapat dikatakan siswa tidak dapat memenuhi indikator proses komunikasi proses komunikasi pada kemampuan literasi matematika. Siswa tidak menuliskan proses mengubah masalah nyata kedalam bentuk matematika, hal ini terlihat dari jawaban siswa dalam memecahkan masalah dan menyimpulkan solusi matematis yang tidak realistic, karena asil akhir siswa sudah akhir siswa belum sampai pada tahap yang ditanya pada soal yaitu panjang masingmasing rusuk persegi, tanpa menggunakan proses awal didapat asil akhir, sehingga siswa tidak dapat memenuhi indikator proses kemampuan matematisasi pada kemampuan literasi matematika. Siswa 
tidak dapat menyajikan kembali objek pada permaslahan matematika, sehingga dapat dikatakan siswa belum memenuhi indikator proses representasi pada kemampuan literasi matematika.

Salah satu faktor pendukung terkait kemampuan literasi matematika adalah gaya belajar (Breen et al., n.d.). Gaya belajar adalah salah satu variabel yang penting dan menyangkut cara pesertadidik memahami pembelajaran disekolah. Gaya belajar yang digunakan akan membuat siswa merasa terbantu dalam menyerap informasi sehingga memudahkan siswa tersebut dalam proses pembelajaran dan berkomunikasi. Setiap orang mempunyai gaya belajar sendiri-sendiri dan tidak dapat dipaksakan untuk menggunakan gaya belajar yang seragam (Edriati, S., Hamdunah \& Astuti, 2013). Guru dengan gaya belajar siswa dapat mengarahkan siswa untuk belajar sesuai dengan gaya belajar yang mereka miliki sehingga dapat dengan mudah menerima pelajaran dan meningkatkan hasil belajarnya (Widayanti, 2013).

Hasil penelitian (Syawahid, M., \& Putrawangsa, 2017) diperoleh bahwa kemampuan literasi matematika siswa dengan gaya belajar siswa memiliki ketercapain menjawab soal literasi matematika sesuai dengan gaya belajar yang mereka miliki dan salah satu acuan dalam pengembangan pembelajaran matematika dengan menyesuaikan metode yang digunakan oleh peserta didik. Sama halnya dengan penelitian (Sari, D, U., Adam, P., Kodirun, 2019) yang menemukan perbedaan kemampuan literasi matematika siswa dengan gaya belajar yang berbeda dalam menyelesaikan soal literasi berdasarkan Quantity, Space and Shape serta Change and Relationsbips. Berdasarkan hasil penelitian yang telah dilakukan oleh peneliti sebelumnya dan permasalahan yang terjadi di SMP N 14 Padang, maka penelitian ini bertujuan untuk menganalisis kemampuan literasi matematika ditinjau dari gaya belajar siswa.

\section{METODE}

Penelitian ini menggunakan metode penelitian deskriptif dengan pendekatan kualitatif yang bertujuan untuk menganalisis kemampuan literasi matematika berdasarkan gaya belajar siswa. Penelitian ini dilakukan di kelas VII SMP Negeri 14 Padang. Pengambilan sampel dilakukan secara purposive sampling. Sebagai sampel adalah kelas VII.6, dengan pertimbangan kelas tersebut mempunyai nilai ulangan semester genap untuk semua siswa di atas Kriteria Ketuntasan Matematika (KKM) yaitu 75, dan dalam proses pembelajaran siswa kelas VII.6 lebih aktif dari pada kelas lainnya.

Instrumen penelitian yang digunakan adalah angket gaya belajar, tes kemampuan literasi matematika, serta pedoman wawancara. Angket gaya belajar menggunakan skala likert dengan pilihan responden Sangat Sering (SS), Sering (S), dan Kadang-Kadang (KD). Pemberian angket gaya belajar bertujuan untuk mengidentifikasi kecenderungan gaya belajar siswa kelas VII SMP Negeri 14 Padang. yang dibuat berdasarkan indicator gaya belajar. Tes kemampuan literasi matematika berupa soal esai pada materi segiempat. Pedoman wawancara yang dilakukan mengacu kepada indicator kemampuan literasi matematika, dan wawancara diambil berdasarkan gaya belajar siswa yang telah dikelompok. 
Teknik pengumpulan data pada penelitian ini dilakukan dengan cara memberikan angket gaya belajar, melakukan tes kemampuan literasi matematika dan wawancara. Pada tabel berikut dapat dilihat indikator dari instrumen penelitian:

Tabel 1. Indikator Gaya Belajar

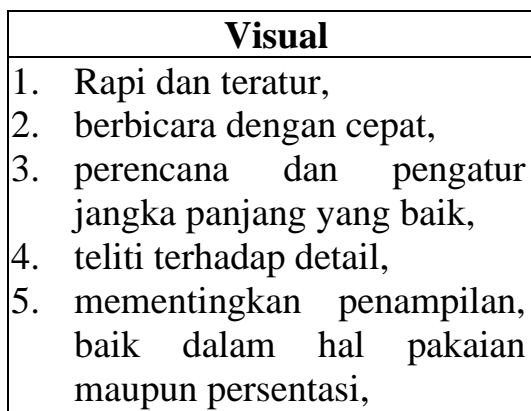

6. pengeja yang baik dan dapat melihat kata-kata yang sebenarnya dalam pikiran mereka,

7. mengingat apa yang dilihat dari pada yang didengar,

8. mengingat dengan asosiasi visual, baisanya tidak terganggu oleh keributan,

9. mempunyai masalah untuk mengingat intruksi verbal kecuali jika ditulis dan sering kali minta bantuan orang untuk mengulanginya,

10. pembaca cepat dan tekun, lebih suka membaca dari pada dibacakan,

11. membutuhkan pandangan dan tujuan yang menyeluruh dan bersikap waspada sebelum secara mental pasti tentang suatu masalah atau proyek,

12. mencoret-coret tanpa arti selama berbicara di telpon dan di dalam rapat,

13. Lupa menyampaikan pesan verbal kepada orang lain,

14. sering menjawab pertanyaan dengan jawaban singkat iya atau tidak,

15. lebih suka melakukan demonstrasi dari pada berpidato,

16. lebih suka seni dari pada musik.

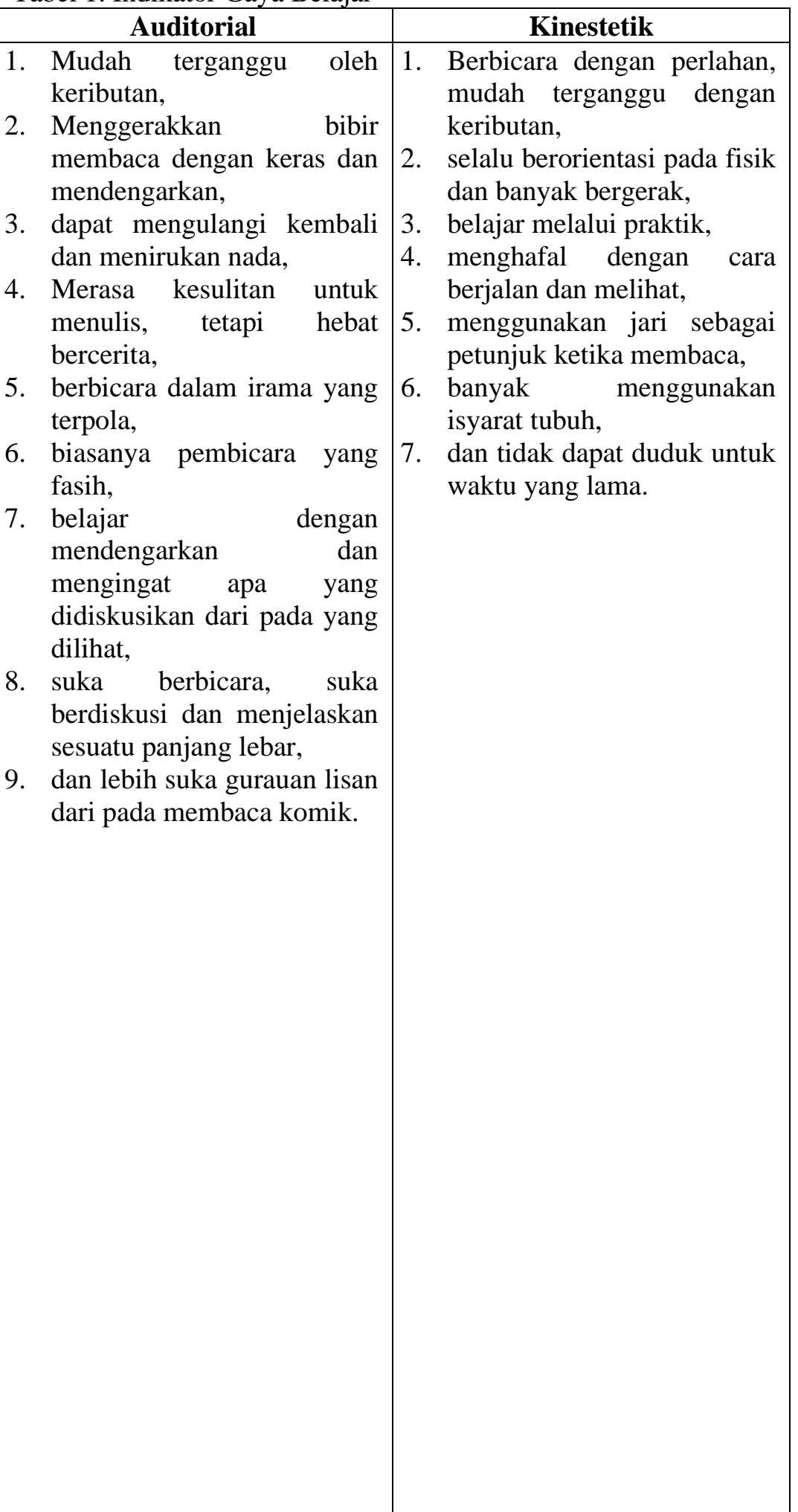


Selanjutnya hasil angket dilakukan penskoran dengan kriteria sebagai berikut:

Tabel 2. Pedoman Penskoran Angket Gaya Belajar

\begin{tabular}{|c|c|}
\hline Keterangan & Skala Likert \\
\hline Sangat Sering & 2 \\
\hline Sering & 1 \\
\hline Kadang-kadang & 0 \\
\hline
\end{tabular}

Sumber: dimodifikasi dari (Porter, Reardon, \& Singer-Nourine, 2010:214)

Berikut indikator kemampuan Literasi Matematika yang digunakan:

Tabel 3. Pedoman Penskoran Berdasarkan Indikator Kemampuan Literasi Matematika

\begin{tabular}{|c|c|c|c|c|c|c|}
\hline \multirow{2}{*}{ Kemampuan } & \multirow{2}{*}{ Indikator } & \multicolumn{5}{|c|}{ Skala } \\
\hline & & \multicolumn{2}{|l|}{0} & & 2 \\
\hline \multirow{2}{*}{ Komunikasi } & $\begin{array}{l}\text { Menuliskan } \\
\text { proses dalam } \\
\text { mencapai solusi }\end{array}$ & \multicolumn{2}{|c|}{$\begin{array}{l}\text { Tidak dapat } \\
\text { menuliskan proses } \\
\text { dalam mencapai } \\
\text { solusi }\end{array}$} & \multicolumn{2}{|c|}{\begin{tabular}{lr}
\multicolumn{2}{c}{ Dapat menuliskan } \\
proses & dalam \\
mencapai & solusi, \\
tetapi & masih \\
belum lengkap
\end{tabular}} & \begin{tabular}{lr}
\multicolumn{2}{c}{ Dapat menuliskan } \\
proses & dalam \\
mencapai solusi, \\
dengan lengkap \\
dan benar
\end{tabular} \\
\hline & $\begin{array}{l}\text { Menyimpulkan } \\
\text { hasil matematika }\end{array}$ & \multicolumn{2}{|c|}{$\begin{array}{l}\text { Tidak dapat } \\
\text { menyimpulkan } \\
\text { hasil matematika }\end{array}$} & \multicolumn{2}{|c|}{$\begin{array}{l}\text { Dapat } \\
\text { menyimpulkan } \\
\text { hasil matematika, } \\
\text { tetapi masih } \\
\text { belum lengkap }\end{array}$} & $\begin{array}{l}\text { Dapat } \\
\text { menyimpulkan } \\
\text { hasil matematika } \\
\text { dengan lengkap } \\
\text { dan benar }\end{array}$ \\
\hline $\begin{array}{l}\text { Kemampuan } \\
\text { matematisasi }\end{array}$ & $\begin{array}{l}\text { Menggunakan } \\
\text { pemahaman } \\
\text { konteks untuk } \\
\text { menyelesaiakan } \\
\text { masalah } \\
\text { matematika }\end{array}$ & \multicolumn{2}{|c|}{$\begin{array}{l}\text { Tidak dapat } \\
\text { menggunakan } \\
\text { pemahaman } \\
\text { konteks untuk } \\
\text { menyelesaikan } \\
\text { masalah } \\
\text { matematika }\end{array}$} & \multicolumn{2}{|c|}{$\begin{array}{l}\text { Dapat } \\
\text { menggunakan } \\
\text { pemahaman } \\
\text { konteks untuk } \\
\text { menyelesaikan } \\
\text { masalah } \\
\text { matematika, } \\
\text { tetapi belum } \\
\text { lengkap }\end{array}$} & $\begin{array}{l}\text { Dapat } \\
\text { menggunakan } \\
\text { pemahaman } \\
\text { konteks untuk } \\
\text { menyelesaikan } \\
\text { masalah } \\
\text { matematika } \\
\text { dengan lengkap } \\
\text { dan benar }\end{array}$ \\
\hline \multirow{2}{*}{$\begin{array}{l}\text { Kemampuan } \\
\text { representasi }\end{array}$} & $\begin{array}{l}\text { Menghubungkan } \\
\text { berbagai macam } \\
\text { representasi saat } \\
\text { menyelesaikan } \\
\text { masalah }\end{array}$ & \multicolumn{2}{|c|}{$\begin{array}{l}\text { Tidak dapat } \\
\text { Menghubungkan } \\
\text { berbagai macam } \\
\text { representasi saat } \\
\text { menyelesaikan } \\
\text { masalah }\end{array}$} & \multicolumn{2}{|c|}{$\begin{array}{l}\text { Dapat } \\
\text { Menghubungkan } \\
\text { berbagai macam } \\
\text { representasi saat } \\
\text { menyelesaikan } \\
\text { masalah, tetapi } \\
\text { belum lengkap } \\
\text { dan benar }\end{array}$} & $\begin{array}{l}\text { Dapat } \\
\text { Menghubungkan } \\
\text { berbagai macam } \\
\text { representasi saat } \\
\text { menyelesaikan } \\
\text { masalah, dengan } \\
\text { lengkap dan benar }\end{array}$ \\
\hline & $\begin{array}{l}\text { Menggunakan } \\
\text { berbagai macam } \\
\text { representasi } \\
\text { dalam pemecahan } \\
\text { masalah }\end{array}$ & \multicolumn{2}{|c|}{$\begin{array}{l}\text { Tidak dapat } \\
\text { menggunakan } \\
\text { berbagai macam } \\
\text { representasi dalam } \\
\text { pemecahan } \\
\text { masalah }\end{array}$} & \multicolumn{2}{|c|}{$\begin{array}{l}\text { Dapat } \\
\text { menggunakan } \\
\text { berbagai macam } \\
\text { representasi } \\
\text { dalam pemecahan } \\
\text { masalah, tetapi } \\
\text { belum lengkap }\end{array}$} & $\begin{array}{l}\text { Dapat } \\
\text { menggunakan } \\
\text { berbagai macam } \\
\text { representasi } \\
\text { dalam pemecahan } \\
\text { masalah, dengan } \\
\text { lengkap dan benar }\end{array}$ \\
\hline $\begin{array}{l}\text { Kemampuan } \\
\text { penalaran } \\
\text { dan argumen }\end{array}$ & $\begin{array}{l}\text { Menjelaskan } \\
\text { pembenaran } \\
\text { dalam }\end{array}$ & \multicolumn{3}{|c|}{\begin{tabular}{l|l} 
Tidak dapat & Dapat \\
menjelaska & menjelaskan \\
pembenaran
\end{tabular}} & \multicolumn{2}{|c|}{$\begin{array}{lr}\text { Dapat menjelaskan } \\
\text { pembenaran dalam } \\
\text { menentukan proses dan }\end{array}$} \\
\hline
\end{tabular}




\begin{tabular}{|c|c|c|c|c|}
\hline & $\begin{array}{lr}\text { menentukan } & \\
\text { proses } & \text { dan } \\
\text { prosedur } & \text { yang } \\
\text { digunakan } & \text { untuk } \\
\text { menentukan } & \text { hasil } \\
\text { atau } & \text { solusi } \\
\text { matematis } & \end{array}$ & $\begin{array}{l}\text { pembenaran } \\
\text { dalam } \\
\text { menentukan } \\
\text { proses dan } \\
\text { prosedur } \\
\text { yang } \\
\text { digunakan } \\
\text { untuk } \\
\text { menentukan } \\
\text { hasil atau } \\
\text { solusi } \\
\text { matematis }\end{array}$ & $\begin{array}{lr}\text { dalam } & \\
\text { menentukan } & \\
\text { proses } & \text { dan } \\
\text { prosedur yang } \\
\text { digunakan } & \text { untuk } \\
\text { menentukan } & \text { hasil } \\
\text { atau } & \text { solusi } \\
\text { matematis, tetapi } \\
\text { belum lengkap }\end{array}$ & $\begin{array}{l}\text { prosedur yang } \\
\text { digunakan untuk } \\
\text { menentukan hasil atau } \\
\text { solusi matematis dengan } \\
\text { lengkap dan benar }\end{array}$ \\
\hline & $\begin{array}{l}\text { Menyimpulkan } \\
\text { dari berbagai } \\
\text { argumen } \\
\text { matematis }\end{array}$ & $\begin{array}{l}\text { Tidak dapat } \\
\text { menyimpul } \\
\text { kan dari } \\
\text { berbagai } \\
\text { argumen } \\
\text { matematis }\end{array}$ & $\begin{array}{l}\text { Dapat } \\
\text { menyimpulkan } \\
\text { dari berbagai } \\
\text { argumen } \\
\text { matematis tetapi } \\
\text { belum lengkap } \\
\text { dan benar }\end{array}$ & $\begin{array}{l}\text { Dapat menyimpulkan } \\
\text { dari berbagai argumen } \\
\text { matematis, dengan } \\
\text { lengkap dan benar }\end{array}$ \\
\hline $\begin{array}{l}\text { Kemampuan } \\
\text { memilih } \\
\text { strategi untuk } \\
\text { memecahkan } \\
\text { masalah }\end{array}$ & $\begin{array}{l}\text { Menggunakan } \\
\text { strategi melalui } \\
\text { berbagai prosedur } \\
\text { yang mengarah } \\
\text { kepada solusi dan } \\
\text { kesimpulan } \\
\text { matemati }\end{array}$ & $\begin{array}{l}\text { Tidak dapat } \\
\text { menggunak } \\
\text { an strategi } \\
\text { melalui } \\
\text { berbagai } \\
\text { prosedur } \\
\text { yang } \\
\text { mengarah } \\
\text { kepada } \\
\text { solusi dan } \\
\text { kesimpulan } \\
\text { matematis }\end{array}$ & $\begin{array}{l}\text { Dapat } \\
\text { menggunakan } \\
\text { strategi melalui } \\
\text { berbagai prosedur } \\
\text { yang mengarah } \\
\text { kepada solusi dan } \\
\text { kesimpulan } \\
\text { matematis, tetapi } \\
\text { belum lengkap } \\
\text { dan benar }\end{array}$ & $\begin{array}{l}\text { Dapat menggunakan } \\
\text { strategi melalui berbagai } \\
\text { prosedur yang mengarah } \\
\text { kepada solusi dan } \\
\text { kesimpulan matematis, } \\
\text { dengan lengkap dan } \\
\text { benar }\end{array}$ \\
\hline $\begin{array}{l}\text { Kemampuan } \\
\text { menggunakan } \\
\text { bahasa dan } \\
\text { operasi } \\
\text { simbolis, } \\
\text { formal dan } \\
\text { teknis }\end{array}$ & $\begin{array}{l}\text { Menggunakan } \\
\text { bentuk formal } \\
\text { berdasarkan } \\
\text { definisi dan } \\
\text { aturan } \\
\text { matematika }\end{array}$ & $\begin{array}{l}\text { Tidak dapat } \\
\text { menggunak } \\
\text { an bentuk } \\
\text { formal } \\
\text { berdasarkan } \\
\text { definisi dan } \\
\text { aturan } \\
\text { matematika }\end{array}$ & $\begin{array}{l}\text { Dapat } \\
\text { menggunakan } \\
\text { bentuk formal } \\
\text { berdasarkan } \\
\text { definisi dan aturan } \\
\text { matematika, tetapi } \\
\text { belum lengkap } \\
\text { dan benar }\end{array}$ & $\begin{array}{lr}\text { Dapat } & \text { menggunakan } \\
\text { bentuk } & \text { formal } \\
\text { berdasarkan definisi dan } \\
\text { aturan matematika, } \\
\text { dengan lengkap dan } \\
\text { benar }\end{array}$ \\
\hline $\begin{array}{l}\text { Kemampuan } \\
\text { menggunakan } \\
\text { alat-alat } \\
\text { matematika }\end{array}$ & $\begin{array}{l}\text { Menggunakan } \\
\text { alat-alat } \\
\text { matematika untuk } \\
\text { mengenali } \\
\text { struktur } \\
\text { matematika atau } \\
\text { untuk }\end{array}$ & $\begin{array}{l}\text { Tidak dapat } \\
\text { menggunak } \\
\text { an alat-alat } \\
\text { matematika } \\
\text { untuk } \\
\text { mengenali } \\
\text { struktur }\end{array}$ & $\begin{array}{l}\text { Dapat } \\
\text { menggunakan } \\
\text { alat-alat } \\
\text { matematika untuk } \\
\text { mengenali struktur } \\
\text { matematika atau } \\
\text { untuk }\end{array}$ & $\begin{array}{lr}\text { Dapat } & \text { menggunakan } \\
\text { alat-alat } & \text { matematika } \\
\text { untuk } & \text { mengenali } \\
\text { struktur } & \text { matematika } \\
\text { atau } & \text { untuk } \\
\text { menggambarkan } \\
\text { hubungan matematis, }\end{array}$ \\
\hline
\end{tabular}




\begin{tabular}{|l|l|l|l|ll|}
\hline & menggambarkan & matematika & menggambarkan & dengan lengkap dan \\
hubungan & atau untuk \\
mengabamatis & $\begin{array}{l}\text { mengan } \\
\text { rkan } \\
\text { hubungan } \\
\text { matematis }\end{array}$ & $\begin{array}{l}\text { benar } \\
\text { belum lumatis, tetapi } \\
\text { dan benar }\end{array}$ & & \\
& & & & \\
\end{tabular}

Sumber : Dimodifikasi dari (Anggrieni \& Putri, 2018)

Teknik analisis data yang diguakan yakni 1) Reduksi data yang merupakan bentuk analisis yang memuat menggolongkan, membuang yang tidak perlu dan mengorganisasikan data mentah yang diperoleh dari lapangan. 2) penyajian data yang telah direduksi yang akan disajikan secara tertulis, yang sudah diorganisir dan diketagorikan sehingga mempermudah untuk menarik kesimpulan. 3) Penarikan kesimpulan berupa memberi makna dan penjelasan berdasarkan data yang telah disajikan (Sugiyono, 2013).

\section{HASIL DAN DISKUSI}

Berdasarkan penelitian yang dilakukan dapat diklasifikasikan kemampuan literasi matematika siswa berdasarkan gaya belajar sebagai berikut:

\section{Kemampuan Literasi Matematika siswa berdasarkan gaya belajar Visual}

Tabel 4. Capaian Literasi Matematika Siswa Dengan Gaya Belajar Visual

\begin{tabular}{|c|c|c|l|}
\hline No & Kode Siswa & Level & Kompetensi Kemampuan Literasi Matematika \\
\hline 1 & AC & 2 & Reproduksi \\
\hline 2 & GC & 2 & Reproduksi \\
\hline 3 & HD & 2 & Reproduksi \\
\hline 4 & SAT & 2 & Reproduksi \\
\hline 5 & WS & 2 & Reproduksi \\
\hline 6 & RF & 2 & Reproduksi \\
\hline 7 & REF & 2 & Reproduksi \\
\hline 8 & SF & 2 & Reproduksi \\
\hline 9 & SM & 3 & Koneksi \\
\hline 10 & IV & 3 & Koneksi \\
\hline 11 & WA & 3 & Koneksi \\
\hline 12 & NS & 3 & Koneksi \\
\hline
\end{tabular}

Berdasarkan Tabel 5, diperoleh siswa dengan gaya belajar visual memiliki kemampuan literasi matematika pada kompetensi reproduksi sebanyak 8 orang siswa sedangkan kemampuan koneksi 4 orang siswa. Percapaian siswa dengan kompetensi literasi matematika siswa dengan gaya belajar visual masih banyak siswa belum mencapai level koneksi.

\section{Kemampuan Literasi Matematika Siswa Ditinjau Dari Gaya Belajar Auditorial}

Berdasarkan hasil tes kemampuan Literasi Matematika siswa dengan gaya belajar Auditorial, pencapaian level kompetensi literasi matematika dapat dilihat pada Tabel 5 berikut. 
Tabel 5. Capaian Literasi Matematika Siswa Dengan Gaya Belajar Auditorial

\begin{tabular}{|c|c|c|c|}
\hline No & $\begin{array}{c}\text { Kode } \\
\text { Siswa }\end{array}$ & Level & $\begin{array}{c}\text { Kompetensi Kemampuan Literasi } \\
\text { Matematika }\end{array}$ \\
\hline 1 & FJ & 2 & Reproduksi \\
\hline 2 & FF & 2 & Reproduksi \\
\hline 3 & MI & 2 & Reproduksi \\
\hline 4 & MR & 2 & Reproduksi \\
\hline 5 & MS & 2 & Reproduksi \\
\hline 6 & SFG & 2 & Reproduksi \\
\hline 7 & AL & 3 & Koneksi \\
\hline 8 & DA & 3 & Koneksi \\
\hline 9 & RR & 3 & Koneksi \\
\hline 10 & ZY & 3 & Koneksi \\
\hline
\end{tabular}

Berdasarkan Tabel 5, diperoleh bahwa siswa dengan gaya belajar auditorial ada yang mencapai level paling tinggi dengan kompetensi Koneksi. Siswa dengan gaya belajar auditorial hanya bisa menyelesaikan soal pada kompetensi reproduksi dan kompetensi koneksi. Percapaian siswa dengan kompetensi literasi matematika siswa dengan gaya belajar auditorial mayoritas mencapai level reproduksi yakni sebanyak 6 orang.

\section{Kemampuan Literasi Matematika Siswa Ditinjau dari Gaya Belajar Kinestetik}

Berdasarkan hasil tes kemampuan Literasi Matematika siswa dengan gaya belajar Kinestetik, pencapaian level kompetensi literasi matematika dapat dilihat pada Tabel 6 berikut.

Tabel 6. Capaian Literasi Matematika Siswa Dengan Gaya Belajar Kinestetik

\begin{tabular}{|c|c|c|l|}
\hline No & $\begin{array}{c}\text { Kode } \\
\text { Siswa }\end{array}$ & Level & \multicolumn{1}{|c|}{$\begin{array}{c}\text { Kompetensi Kemampuan Literasi } \\
\text { Matematika }\end{array}$} \\
\hline 1 & AH & 1 & Reproduksi \\
\hline 2 & HR & 3 & Koneksi \\
\hline 3 & HI & 3 & Koneksi \\
\hline 4 & IF & 3 & Koneksi \\
\hline 5 & JF & 3 & Koneksi \\
\hline 6 & SD & 3 & Koneksi \\
\hline 7 & SFF & 3 & Koneksi \\
\hline
\end{tabular}

Berdasarkan Tabel 6, diperoleh bahwa Siswa dengan gaya belajar kinestetik ada yang mencapai level paling tinggi yaitu level 3 dengan kompetensi kemampuan literasi matematika koneksi, dari ke tujuh siswa dengan gaya belajar kinestetik terdapat 6 siswa mencapai pada level 3 dengan kompetensi kemampuan literasi matematika Koneksi, dan 1 siswa mencapai level 1 dengan kompetensi kemampuan literasi matematika reproduksi. Berikut dapat disajikan hasil analisis angket gaya belajar dan kemampuan literasi matematika siswa secara bersama-sama. 
Tabel 7. Hasil Tes Kemampuan literasi matematika berdasarkan gaya belajar

\begin{tabular}{|l|c|c|c|}
\hline Literasi Gaya Belajar & Reproduksi & Koneksi & Jumlah \\
\hline Visual & 8 & 4 & 12 \\
\hline Auditorial & 6 & 4 & 10 \\
\hline Kinestetik & 1 & 6 & 7 \\
\hline Visual-Kinestetik & 1 & 1 & 2 \\
\hline Visual-Auditorial & 1 & 0 & 1 \\
\hline Jumlah & 16 & 16 & 32 \\
\hline
\end{tabular}

Hasil analisis gaya belajar pada tabel 8 diatas ditemukan bahwa siswa yang menjadi subjek penelitian paling banyak memiliki gaya belajar visual, Auditorial, dan Kinestetik. Kemudian hasil kemampuan lietrasi matematika berdasarkan gaya belajar dapat dideskripsikan; 1) siswa yang memiliki gaya belajar visual lebih banyak memiliki kemampuan literasi matematika kompetensi reproduksi dibandingkan dengan kompetensi koneksi, 2) siswa dengan gaya belajar auditorial memiliki kemampuan literasi matematika kompetensi reproduksi lebih banyak dibandingkan dengan kompetensi koneksi, 3) Siswa yang memiliki gaya belajar kinestetik lebih banyak memiliki kemampuan literasi kompetensi koneksi, 4) sedang siswa yang memiliki gaya belajar visual-kinestetik itu hanya ada satu orang, dan memiliki kemmapuan literasi pada kompetensi reproduksi dan koneksi, 5) siswa yang memiliki gaya belajar visual-auditori juga satu orang dimana kemampuan literasi matematikanya berada pada kompetensi reproduksi.

\section{Diskusi}

Berdasarkan hasil penelitian yang dilakukan di kelas VII SMPN 14 Padang diperloleh gambaran bahwa gaya belajar siswa cenderung bersifat visual dan auditorial. Hal ini sesuai dengan hasil penelitian yang dilakukan oleh (Nariyati, R. Y., Halini \&BS, 2010) juga menemukan bahwa gaya belajar paling dominan yaitu gaya belajar Visual (40,91\%). Menurut (Fathani, A, 2016) gaya belajar siswa tidak berlaku tetap dan permanen, melainkan suatu kecendrungan. Kemudian kemampuan literasi matematika siswa berdasarkan gaya belajar, juga dapat disimpulkan bahwa siswa dengan gaya belajar visual dan auditori memiliki kemampuan literasi matematika kompetensi reproduksi, dan siswa dengan gaya belajar kinestetik memiliki kemampuan lietrasi matematika kompetensi koneksi. Hal ini dapat disimpulkan bahwa siswa dengan gaya belajar visual dan auditori hanya mempu merproduksi represntasi defenisi dan fakta, serta menafsirkan representasi sederhana dan hanya mampu menyelesaikan masalah yang familiar atau yang bersifat rutin dan dapat melakukan perhitungan sederhana. Untuk kelompok siswa yang memiliki gaya belajar kinestetik siswa sudah siswa untuk mengintegrasikan dan menghubungkan seluruh konten, situasi dan representasi penyelesaian masalah non rutin, interpretasi situasi masalah dan pernyataan matematika dengan menggunakan beberapa metode yang jelas terlibat dalam penalaran matematika yang sederhana. Berikut uraian kemampuan lietrasi matematika siswa berdasarkan gaya belajar:

Siswa dengan gaya belajar Visual pada berada pada kompetensi Reproduksi berjumlah 8 orang 
siswa dimana ketujuh siswa tersebut hanya dapat mengerjakan soal dengan kompetensi reproduksi dengan benar, hal ini dikarenakan soal kompetensi reproduksi merupakan soal dengan pertanyaan dan konteks yang dikenal serta semua informasi yang relevan tersedia dengan pertanyaan yang jelas, serta siswa mudah menafsirkan dan mengenali situasi dengan konteks yang memerlukan kesimpulan lansung. Siswa yang mencapai kompetensi koneksi berjumlah 4 orang siswa. Siswa pada kompetensi ini mampu mengerjakan soal yang membuat siswa diminta untuk melakukan prosedur dengan jelas, termasuk prosedur yang memerlukan keputusan secara berurutan, bekerja secara sfektik dengan model untuk untuk situasi yang konkret tetapi kompleks yang mungkin melibatkan pembatasan untuk membuat asumsi.

Contoh hasil kerja siswa dengan gaya belajar visual dengan kompetensi Reproduksi yang diwakili oleh subjek SF. untuk Kemampuan komunikasi SF dapat menerjemahkan pernyataan, pertanyaan, objek dan gambar. Ini terlihat pada kolom a digambar 1. Dimana siswa telah dapat menerjemahkan informasi yang ada pada soal kedalam bentuk gambar. Selanjudnya untuk kemampuan matematisasi, siswa dapat mengidentifikasi informasi dan menyelesaikan struktur matematika yang sudah biasa digunakan atau struktur rutin. Ini terlihat dari jawaban subjek SF di kolom b pada gambar 1. Pada kemampuan representasi SF dapat menyajikan kembali suatu objek dari informasi dunia nyata dengan lengkap, ini terlihat dari gambar yang memenuhi kolom c. Kemampuan penalaran dan argumen subjek SF dapat dilihat bahwa SF menjelaskan pembenaran untuk representasi memenuhi kolom d ini terlihat pada gambar 1. Kemampuan memilih strategi untuk memecahkan masalah subjek SF terlihat pada gambar 1 SF dapat menyimpulkan hasil matematika dengan tepat dan benar ini telah terlihat pada kolom e. Kemampuan menggunakan bahasa dan operasi simbolis, formal dan teknik siswa dapat menggunakan bahasa simbolis, variable yang sesuai untuk mempresentasikan masalah dunia nyata dengan benar terlihat pada kolom f. kemampuan menggunakan alat-alat matenatika subjek SF dapat menggunakan alat- alat matematika untuk mengenali struktur matematika atau menggambarkan hubungan matematis dengan tepat dan benar seperti yang terlihat pada jawaban subjek SF berupa gambar memenuhi kolom g. Sehingga subjek SF memenuhi 10 indikator kemampuan matematika dalam soal no 1 dan memiliki total skor 22.

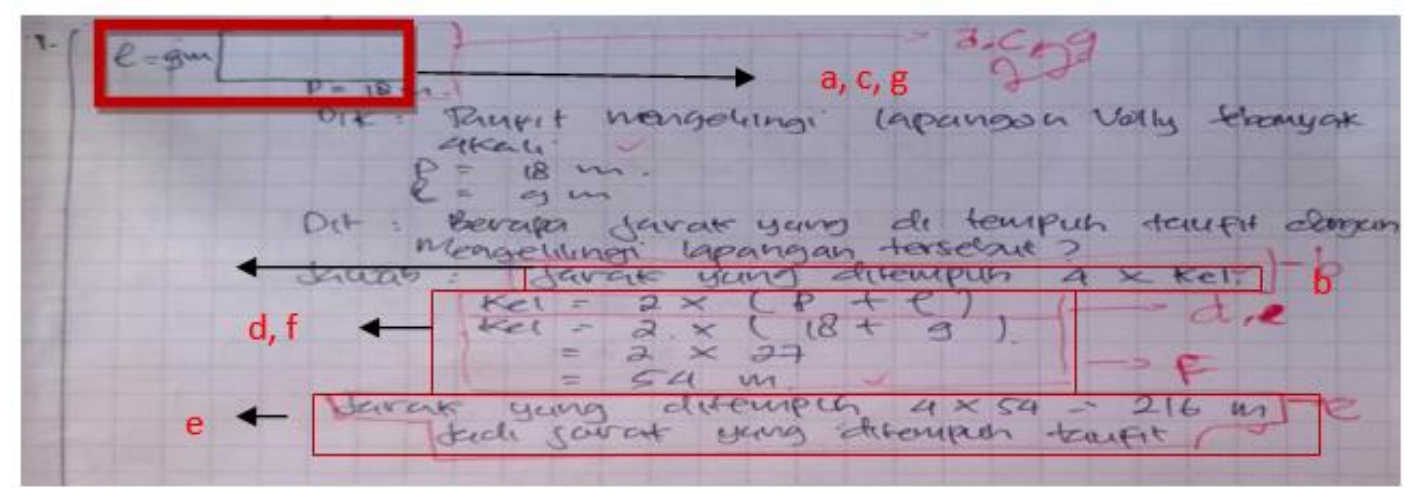

Gambar 1. Jawaban subjek SF soal level 1 
Berikut juga dapat dilihat jawaban subjek SF soal level 2, sebagai berikut:

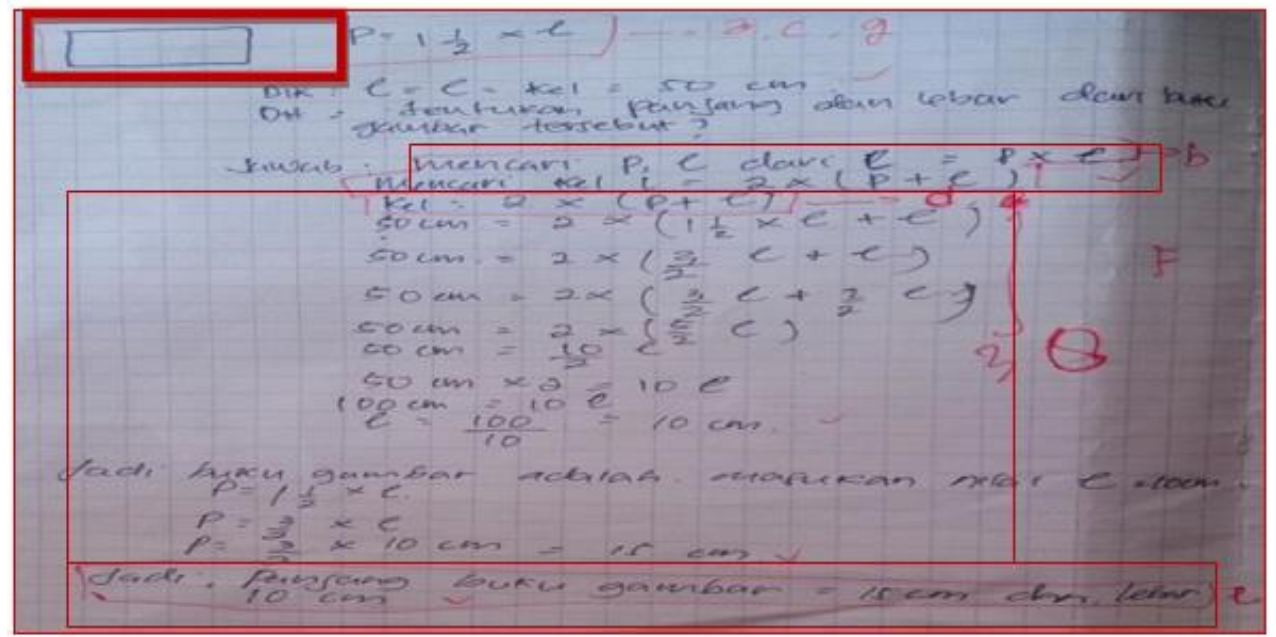

Gambar 2. Jawaban subjek SF soal level 2

Berdasarkan subjek SF diatas, kemampuan komunikasi subjek SF dapat menerjemahkan pernyataan. Pernyataan dengan lengkap memenuhi kolom a terlihat dimana siswa telah dapat menerjemahkan soal. Selanjudnya untuk kemampuan matematisasi, subjek SF dapat mengidentifikasi variable dan struktur matematika yang sudah biasa digunakan terlihat pada kolom b pada gambar 3 . Kemampuan representasi subjek SF dapat membuat representasi dari informasi dunia nyata dengan lengkap. jawaban SF mampu merepresentasikan soal dan dapat menyajikan kembali suatu objek dari informasi dunia nyata dan lengkap, ini terlihat pada kolom c. Kemampuan penalaran dan argumen subjek SF dapat menjelaskan pembenaran pada jawaban SF terlihat pada kolom d pada gambar. Kemampuan memilih strategi untuk memecahkan masalah subjek SF dapat menuliskan dan menjelaskan langkah-langkah penyelesaian yang ditemukan subjek SF dengan prosedur yang mengarah kepada solusi ini terlihat pada kolom e pada gambar 3. Kemampuan menggunakan bahasa dan operasi simbolis, formal dan teknis siswa dapat menggunakan dan memahami bahasa simbolis, variabel yang sesuai untuk merepresentasikan masalah ini terlihat pada kolom $\mathrm{f}$ dari jawaban subjek SF. Kemampuan menggunakan alat-alat matematika yaitu subjek SF dapat menggunakan alat-alat matematika untuk mengenali struktur matematika atau untuk menggambarkan hubungan matematis ini terlihat kolom g pada gambar. Subjek SF dapat mengerjakan soal no 2 dengan benar dengan memenuhi setiap indikato kemampuan literasi matematikan dengan total skror yaitu 38. Selanjutnya dapat dilihat jawaban SF pada soal level 3 seperti terlihat pada gambar 3.

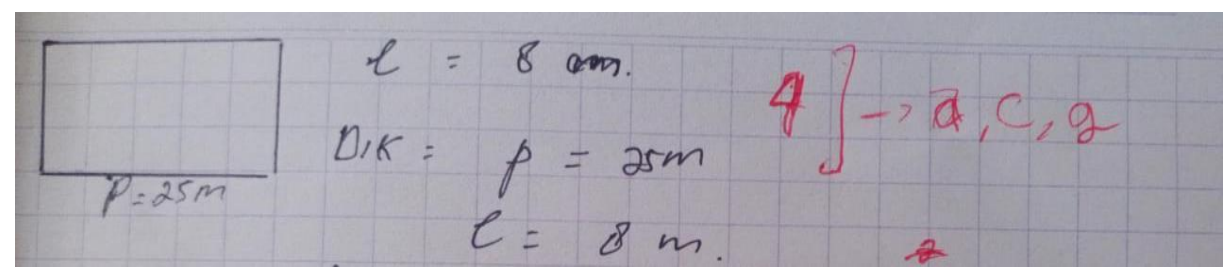

Gambar 3. Jawaban subjek SF soal level 3 
Berdasarkan jawaban subjek SF pada soal level 3, Subjek SF hanya membuatkan gambar tetapi tidak menyelesaikan soal level 3 tersebut. Sehingga kemampuan yang terpenuhi hanya kemampuan menggunakan alat-alat matematika dengan tepat ini terlihat pada kolom g. Subjek SF hanya mengerjakan soal level 1,2 , tan 3 , soal level 1, dan 2 dengan benar sedangkan soal level 3 subjek SF mencoba untuk menyelesaikannya tapi belum lengkap. Sehingga subjek SF hanya memenuhi 3 indikator yaitu indikator a, c, g sehingga subjek SF memiliki total Skor 12. Berdasarkan hasil wawancara dengan subjek SF diperoleh informasi bahwa subjek SF hanya mengerti soal level 1 dan soal level 2, sebab soal nya masih dalam bentuk soal yang mudah dan yang ditanya sangat jelas sekali. Sedangkan soal level 3 subjek SF tidak menyelesaikannya karena sulit untuk dipahami dan soalnya terlalu panjang. Sehingga dapat disimpulkan bahwa subjek SF hanya berada pada level 2 dengan kompetensi Reproduksi. Selanjutnya dapat kita lihat jawaban siswa dengan gaya belajar visual dengan kemampuan literasi berada pada kompetensi koneksi, Analisis jawaban siswa dengan kompetensi koneksi diwakili oleh subjek IV.

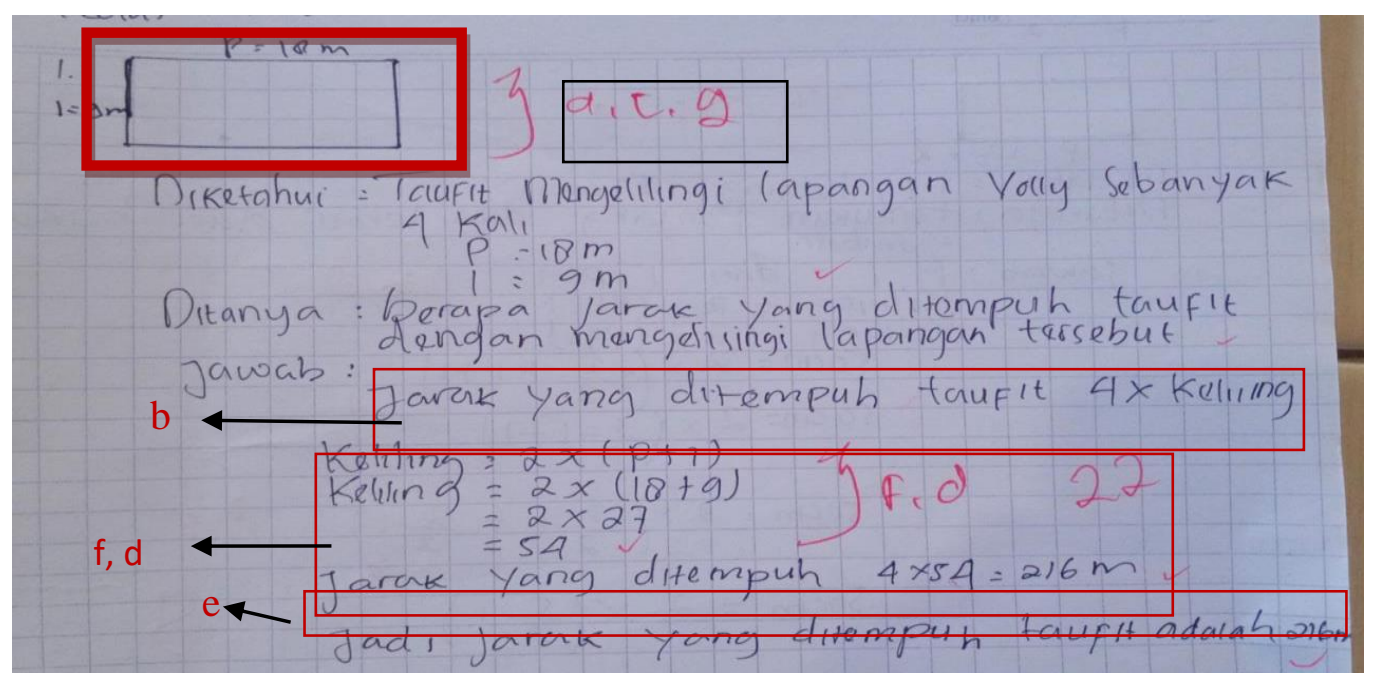

Gambar 4. Jawaban subjek IV soal level 1

Berdasarkan jawaban subjek IV di atas, kemampuan komunikasi subjek IV dapat menerjemahkan pernyataan, pertanyaan, ini terlihat pada kolom a pada gambar 4. Dimana siswa telah dapat menerjemahkan informasi yang ada pada soal kedalam bentuk gambar. Selanjudnya untuk kemampuan matematisasi, subjek IV dapat mengidentifikasi variabel dan struktur matematika yang sudah biasa digunakan atau struktur rutin ini terlihat pada jawaban Subjek IV pada kolom b. Kemampuan representasi yaitu subjek penelitian dapat membuat representasi matematika dari informasi dengan benar dan dapat menyajikan kembali suatu objek dari dunia nyata dengan lengkap, ini terlihat dari jawaban subjek IV pada kolom c. Kemampuan penalaran dan argumen subjek IV dapat dari bahwa IV menjelaskan pembenaran untuk representasi situasi dunia nyata dengan benar. Ini terlihat dari jawaban subjek IV pada kolom d. Kemampuan memilih strategi untuk memecahkan masalah subjek IV dapat menuliskan prosedur penggunaan strategi dalam mencapai solusi dan 
kesimpulan matematika subjek IV dapat menuliskan dan menjelaskan langkah-langkah penyelesaian yang ditemukan yang mengarah pada solusi dan kesimpulan matematka dengan benar Ini terlihat dari jawaban subjek IV pada kolom e. Kemampuan menggunakan bahasa dan operasi simbolis, formal dan teknis siswa dapat menggunakan bahasa dan operasi simbol yang sesuai untuk merepresentasikan masalah dunia nyata dengan benar ini terlihat pada kolom $\mathrm{f}$. Kemampuan menggunakan alat-alat matematika yaitu subjek IV dapat menggunakan alat-alat matematika untuk mengenali struktur matematika atau untuk menggambarkan hubungan matematis terlihat dari gambar yang memenuhi kolom g sehingga subjek IV dapat memenuhi ke 10 indikator kemampuan literasi matematika yang memiliki total skor 22 pada soal nomor 1.

Brdasarkan hasil tes kemampuan literasi matematika diperoleh bahwa siswa dengan gaya belajar Auditorial mencapai kompetensi reproduksi sebanyak 6 orang siwa dan siswa dengan kompetensi koneksi sebanyak 4 orang siswa. Ciri- ciri siswa dengan gaya belajar Auditorial adalah siswa merasa kesulitan dalam menulis dan siswa belajar dengan mendengarkan serta mengingat yang didiskusikan (Deporter, B., \& Hernacki, 2013). Hal ini yang mungkin menjadi penyebab siswa dengan gaya belajar Auditorial paling banyak hanya mencapai kompetensi Reproduksi, sedangkan terdapat beberapa orang yang sampai pada kompetensi koneksi dikarenakan ciri- ciri siswa yang mendengarkan dan mengingat apa yang didiskusikan.Berikut dapat juga dilihat jawaban siswa dengan gaya belajar auditorial untuk komponen reproduksi yang diwakili oleh MI. Hasil jawaban dapat dilihat pada gambar 5 .

Berdasarkan hasil jawaban subjek MI pada soal level 1 di atas, kemampuan komunikasi subjek MI dapat menerjemahkan pertanyataan, pertanyaan, objek dan gambar. Ini terlihat pada kolom a digambar 5. Dimana siswa telah dapat menerjemahkan informasi yang ada pada soal kedalam bentuk gambar. Selanjudnya untuk kemampuan matematisasi subjek MI dapat mengidentifikasi variabel dan struktur matematika yang sudah biasa digunakan atau struktur rutin. Ini terlihat dari jawaban Subjek MI dikolom b pada gambar 5. Kemampuan representasi MI dapat menyajikan kembali suatu objek dari informasi dunia nyata dengan lengkap, ini terlihat dari gambar yang memenuhi kolom c. Kemampuan penalaran dan argumen subjek MI dapat menjelaskan pembenaran dalam menentukan proses dengan menjabarkan jawaban ini terlihat pada kolom d. Kemampuan memilih strategi untuk memecahkan masalah subjek MI dapat menggunakan strategi melalui prosedur yang mengarah kepada solusi dan kesimpulan matematika ini terlihat pada kolom e. Kemampuan menggunakan bahasa dan operasi simbol, formal dan teknis yaitu subjek MI dapat menggunakan variabel dan simbol untuk merepresentasikan masalah dunia nyata dengan menggunakan bahasa simbolis dengan memenuhi kolom $\mathrm{f}$. Kemampuan menggunakan alat-alat matematika subjek MI dapat menggunakan alat-alat matematika untuk mengenali struktur matematika dengan memenuhi kolom g. Jawaban pada subjek MI pada soal nomor 1 dapat memenuhi semua indikator kemempuan literasi matematika yang memiliki total skor 22 ini terlihat pada gambar. 


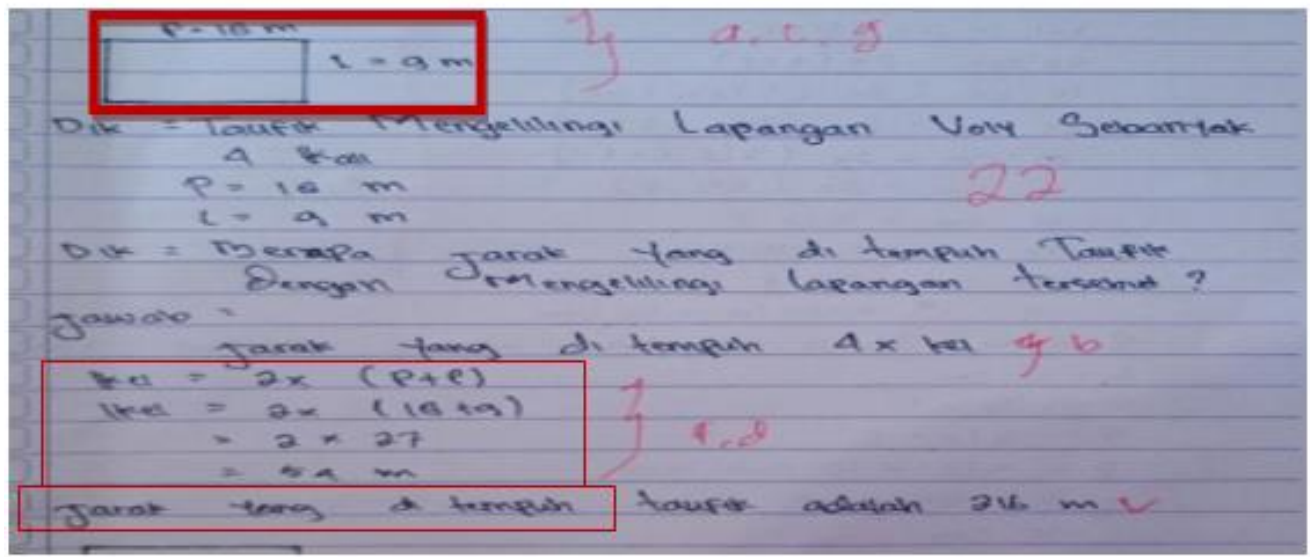

Gambar 5. Jawaban subjek MI soal level 1

Selanjutnya juga dapat dilihat penyelesaian soal oleh siswa dengan gaya belajar Auditorial dengan komponen reproduksi pada soal level 2.

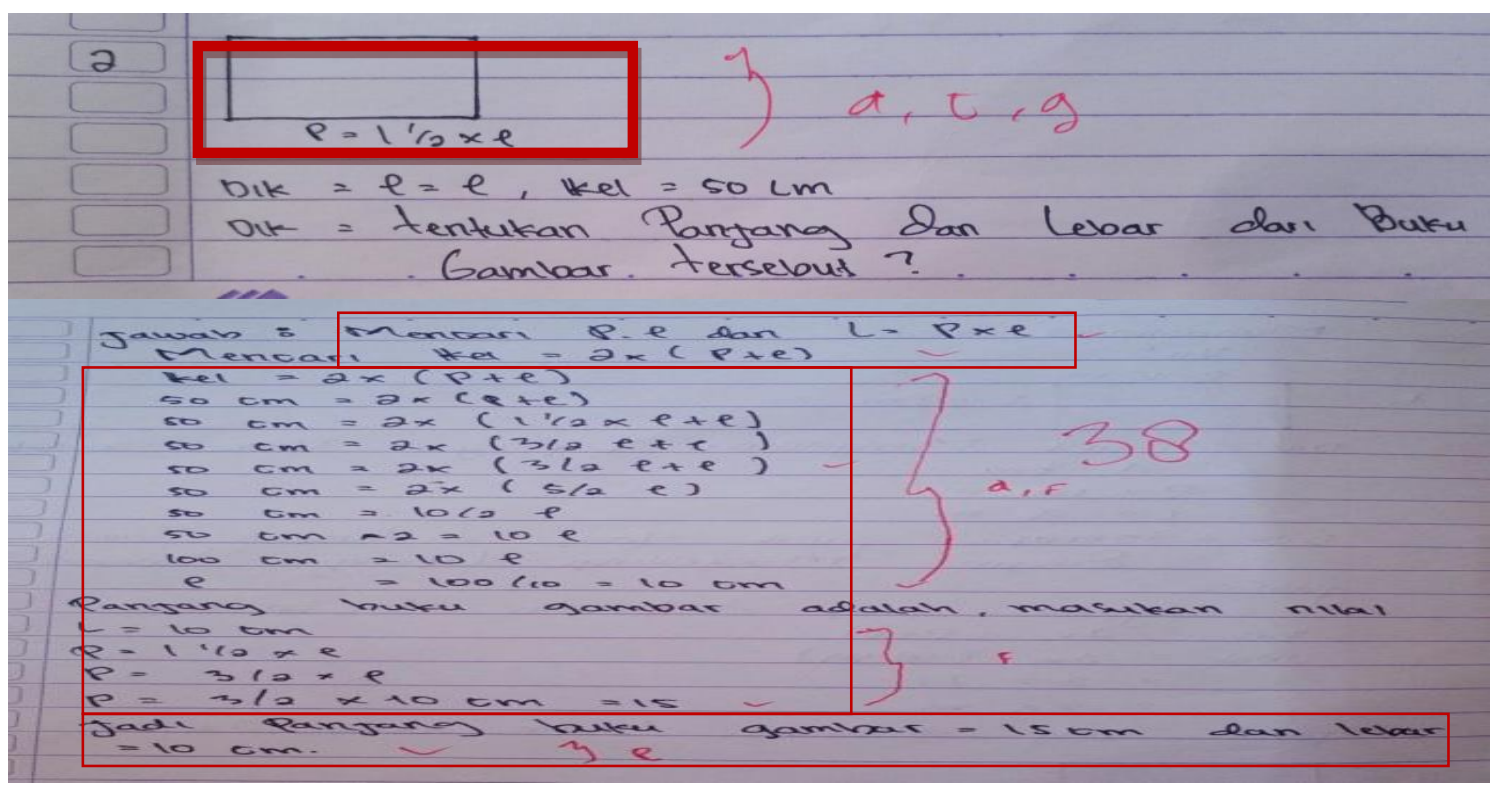

Gambar 6. Jawaban subjek MI soal level 2

Berdasarkan hasil jawaban subjek MI pada soal level 2 di atas, kemampuan komunikasi subjek MI dapat menuliskan proses dalam mencapai solusi dan menyimpulkan hasil matematika ini terlihat dari gambar pada kolom a. Kemampuan matematisasi subjek MI dapat mengidentifikasi variabel dan struktur matematika serta menggunakan pemahaman konteks untuk menyelesaikan masalah ini terlihat pada kolom b. Kemampuan representasi subjek MI dapat membuat representasi matematika dari informasi dunia nyata dengan benar ini terlihat pada kolom c. Kemampuan penalaran dan argumen subjek MI dapat menjelaskan pembenaran dalam menentukan proses dengan menjabarkan jawaban ini terlihat dari gambar pada kolom d. Kemampuan memilih strategi untuk memecahkan masalah subjek MI dapat menggunakan strategi melalui prosedur yang mengarah 
kepada solusi dan kesimpulan matematika. Kemampuan menggunakan bahasa dan operasi simbol, formal dan teknis subjek MI dapat menggunakan variabel dan simbol untuk merepresentasikan masalah dunia nyata dengan menggunakan bahasa simbolis dengan benar ini terlihat dari jawaban pada kolom f. Kemampuan menggunakan alat-alat matematika subjek MI dapat menggunakan alatalat matematika untuk mengenali struktur matematika atau untuk menggambarkan hubungan matematika ini terlihat pada kolom g. Sehingga jawaban subjek MI pada soal nomor 2 dapat memenuhi senua indikator kemampuan literasi matematika yang memiliki total sckor 38 ini terlihat pada jawaban subjek MI diatas.

Berdasarkan hasil wawancara terhadap subjek MI bahwa subjek MI hanya mampu menyelesaikan soal level 1 dan 2 dimana pertanyaan untuk soal level 1 dan 2 masih jelas dan mudah dimengerti. Sedangkan soal level 3 subjek IS tidak mengerjakan soal tersebut karena kurang paham dengan soal dan tidak tahu langkah pertama yang dilakukan untuk menyelesaikan soal-soal tersebut. Sehingga dapat disimpulkan bahwa subjek MI berada pada level 2 dengan kompetensi reproduksi.

Siswa dengan gaya belajar kinestetik 1 orang memiliki komponen reproduksi dan 6 orang memiliki komponen koneksi. Ciri- ciri siswa dengan gaya belajar kinestetik selalu beroriontasi pada fisik dan belajar melalui praktik diduga menjadi salah satu factor siswa kinestetik banyak mencapai kompetensi koneksi hasil penelitian ini relevan dengan hasil penelitian yang dilakukan oleh (Syawahid, M., \& Putrawangsa, 2017) bahwa siswa dengan gaya belajar kinestetik berada pada kompetensi koneksi.

Contoh hasil kerja siswa yang memiliki gaya belajar kinestetik dengan kompetensi reproduksi diwakili oleh subjek AH yang disajikan pada gambar 7. subjek AH mengerjakan soal level 1 dan soal level 2. Soal level 1 subjek AH dapat menyelesaikannya dengan benar dan memenuhi semua kolom pada kemampuan literasi matematika. Subjek AH mengerjakan soal level 2 tetapi ada kolom yang belum terpenuhi diantaranya adalah kemampuan representasi siswa dituntut untuk dapat merepresentasikan matematika dari informasi dunia nyata belum lengkap terlihat dari jawaban subjek AH, subjek AH tidak memenuhi kolom d. Kemampuan penalaran dan argumen subjek AH tidak dapat menjelaskan pembenaran representasi situasi nyata terlihat dari jawaban subjek AH, subjek AH tidak menjelaskan apa yang akan di cari untuk mengetahui jarak yang ditempuh taufit. Kemampuan menggunakan bahasa dan operasi simbol subjek AH tidak menyimpilkan hasil akhir. Kemampuan menggunakan alat-alat matematika subjek AH belum lengkap, subjek AH tidak membuat posisi panjang dan lebarnya lapangan volly untuk memudahkan dalam menyelesaikan soal level 2 tersebut. 


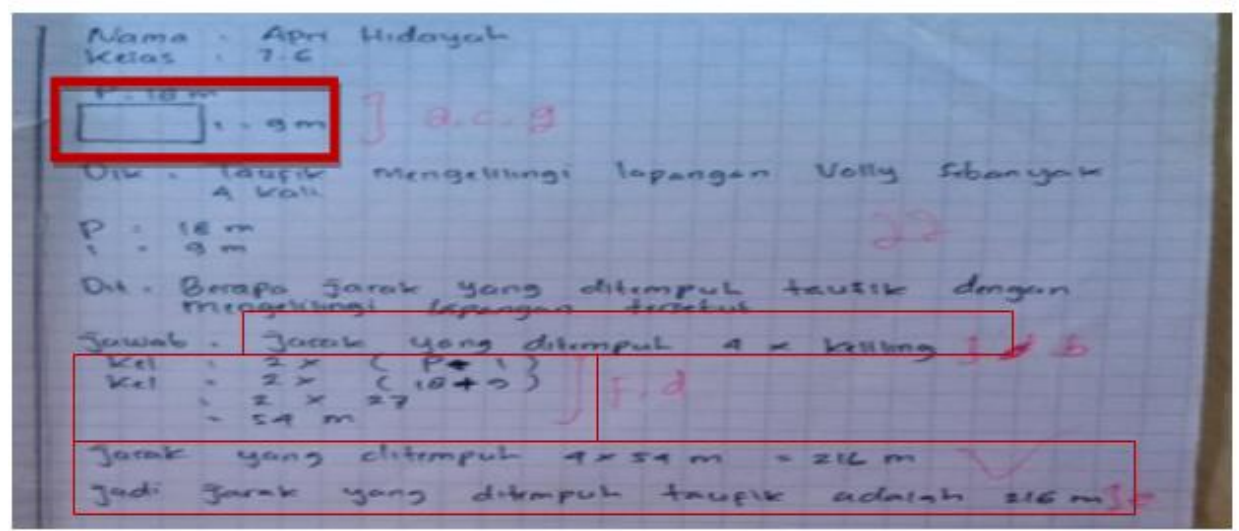

Gambar 7. Jawaban subjek AH soal level 2

Berdasarkan hasil jawaban subjek AH di atas, subjek AH mengerjakan soal level 1 dan soal level 2. Soal level 1 subjek AH dapat menyelesaikannya dengan benar dan memenuhi semua kolom pada kemampuan literasi matematika. Subjek AH mengerjakan soal level 2 tetapi ada kolom yang belum terpenuhi diantaranya adalah kemampuan representasi siswa dituntut untuk dapat merepresentasikan matematika dari informasi dunia nyata belum lengkap terlihat dari jawaban subjek AH, subjek AH tidak memenuhi kolom d. Kemampuan penalaran dan argumen subjek AH tidak dapat menjelaskan pembenaran representasi situasi nyata terlihat dari jawaban subjek $\mathrm{AH}$, subjek $\mathrm{AH}$ tidak menjelaskan apa yang akan di cari untuk mengetahui jarak yang ditempuh taufit. Kemampuan menggunakan bahasa dan operasi simbol subjek AH tidak menyimpilkan hasil akhir. Kemampuan menggunakan alat-alat matematika subjek AH belum lengkap, subjek AH tidak membuat posisi panjang dan lebarnya lapangan volly untuk memudahkan dalam menyelesaikan soal level 2 tersebut. Berdasarkan hasil wawancara terhadap subjek AH diperoleh informasi bahwa subjek AH tidak mengerti dengan soal level 2 dan 3. Subjek AH hanya mampu menyelesaikan soal level 1 dengan pertanyaan yang mudah.

\section{KESIMPULAN}

Berdasarkan hasil penelitian dan pembahasan maka dapat disimpulkan bahwa kecenderungan gaya belajar siswa kelas VII SMP Negeri 14 Padang adalah mayoritas memiliki gaya belajar visual dan kemampuan literasi matematika siswa berdasarkan gaya belajar dapat disimpulkan siswa dengan gaya belajar Visual dan auditori memiliki kemampuan literasi matematika lebih banyak berada pada kompetensi reproduksi dan siswa dengan gaya belajar kinestetik memiliki kemampuan literasi matematika lebih banyak berada pada kompetensi koneksi.

\section{REFERENSI}

Anggrieni, N., \& Putri, R. I. I. (2018). Analisis Kemampuan Literasi Matematika Siswa Kelompok Kecil dalam Menyelesaikan Soal Matematika Tipe PISA. Seminar Nasional Pendidikan Matematika Ahmad Dahlan, (2011), 472-481. 
Breen, S., Cleary, J., \& Shea, A. O. (n.d.). An Investigation of The Mathematical Literacy Of First Year Third Level Students In The Republic Of Ireland An Investigation Of The Mathematical Literacy Of First Year Third Level Students In The Republic of Ireland.

Deporter, B., \& Hernacki, M. (2013). Quantum Learning: Membiasakan Belajar Nyaman dan Menyenangkan. Bandung: Kaifa.

Edriati, S., Hamdunah \& Astuti, R. (2013). Peningkatan Prestasi Belajar Matematika Siswa SMK Melalui Model Quantum Teaching Melibatkan Multiple Intelligence. Cakrawala Pendidikan.

Fathani, A, H. (2016). Gaya Belajar Siswa Dalam Menyelesaikan Masalah Matematik Ditinjau Dari Tingkat Kecenderungan Kecerdasan Matematik dan Linguistik. Proisiding Seminar Matematika Dan Pendidikan Matematika, 2013.

Genc, M., Erbas, A. K., Mathematics, A. K. S., \& Conceptions, T. (2019). Secondary Mathematics Teachers ' Conceptions of Mathematical Literacy To cite this article : Secondary Mathematics Teachers ' Conceptions of Mathematical Literacy.

Khoirudin, A., Setyawati, R. D., \& Nursyahida, F. (2017). Profil Kemampuan Literasi Matematika Siswa Berkemampuan Matematis Rendah Dalam Menyelesaikan Soal Berbentuk PISA. Aksioma.

Nariyati, R. Y., Halini \&BS, dian A. (2010). Literasi Matematis Siswa Pada Konten Change and Relationship. 1-9.

OECD. (n.d.). Asessment and Analytical Framework.

Porter, B. De, Reardon, M., \& Singer-Nourine, S. (2010). Quantum Teaching: Mempraktikkan Quantum Learning di Ruang-Ruang Kelas. Bandung: Kaifa.

Sari, D, U., Adam, P., Kodirun, \& B. (2019). Analisis Kemampuan Literasi Matematis Siswa Kelas VIII SMP Ditinjau Dari Gaya Belajar Dan Perbedaan Gender. Pmbelajaran Berpikir Matematika.

Sugiyono. (2013). Metode Penelitian Kombinasi (Mixed) Methods. Bandung: ALFABETA. cv.

Syawahid, M., \& Putrawangsa, S. (2017). Kemampuan Literasi Matematika Siswa SMA Ditinjau dari Gaya Belajar. Beta (Jurnal Tadris Matematika), 222-240.

Thomson, S., Hillman, K., \& Lisa De Bortoli. (2013). A Teacher 's Guide to PISA Mathematical Literacy.

Widayanti, F. D. (2013). Pentingnya Mengetahui Gaya Belajar Siswa Dalam Kegiatan Pembelajaran Di Kelas. ERUDIO.

Wijaya, A., Heuvel-panhuizen, M. Van Den, Doorman, M., \& Robitzsch, A. (2014). Difficulties in solving context-based PISA mathematics tasks: An analysis of students, errors. The Mathematics Enthusiast the Authors(s)\&Dept.of Mathematical Sciences-The University of Montana, 11(3), 555-584. 